Journal of Southeast Asian

2012

\title{
Labor Market Discrimination: Vietnamese Immigrants
}

Linus Yamane

Pitzer College, LYAMANE@PITZER.EDU

Follow this and additional works at: https://docs.lib.purdue.edu/jsaaea

Part of the Asian American Studies Commons, and the Economics Commons

\section{Recommended Citation}

Yamane, Linus (2012) "Labor Market Discrimination: Vietnamese Immigrants," Journal of Southeast Asian American Education and Advancement. Vol. 7 : Iss. 1, Article 4.

DOI: $10.7771 / 2153-8999.1046$

Available at: https://docs.lib.purdue.edu/jsaaea/vol7/iss1/4

This document has been made available through Purdue e-Pubs, a service of the Purdue University Libraries. Please contact epubs@purdue.edu for additional information.

This is an Open Access journal. This means that it uses a funding model that does not charge readers or their institutions for access. Readers may freely read, download, copy, distribute, print, search, or link to the full texts of articles. This journal is covered under the CC BY-NC-ND license. 


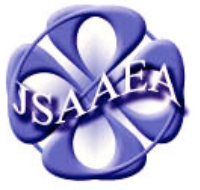

Volume 7 (2012)
Journal of Southeast Asian American Education \& Advancement

WWw.JSAAEA.org
A peer-reviewed scholarly journal published by the National Association for the Education \& Advancement of Cambodian, Laotian, and Vietnamese Americans (NAFEA)

\title{
Labor Market Discrimination: Vietnamese Immigrants
}

\author{
Linus Yamane \\ Pitzer College
}

\begin{abstract}
Vietnamese and East European immigrants face similar obstacles in the U.S. labor market. This provides for an interesting test of racial discrimination in the labor market. Does it make any difference if an immigrant is Asian or White? When Vietnamese immigrants are compared to East European immigrants, Vietnamese men earn 7-9\% less than comparable East European men, with more discrimination among the less educated, and in the larger Vietnamese population centers like California. Vietnamese women earn as much as comparable East European women. Vietnamese immigrants, male and female, are much less likely to hold managerial and supervisory positions than comparable East European immigrants.
\end{abstract}

KEY WORDS: Discrimination, East European American, glass ceilings, immigrants, labor market, Vietnamese American

\section{Introduction}

Do Asian American immigrants experience discrimination in the U.S. labor market? Are they paid as much as comparable non-Hispanic Whites ${ }^{1}$ ? Are they as likely as comparable nonHispanic Whites to be promoted to supervisory and managerial positions? This study makes a contribution to the literature on racial discrimination in the labor market by examining the experience of immigrant Vietnamese Americans.

Most of the literature on racial discrimination in the labor market focuses on the experiences of African Americans (see, e.g., Altonji \& Blank, 1999; Bertrand \& Mullainathan, 2004; Neal \& Johnson, 1996). Smith and Welch (1989), Card and Krueger (1992), O’Neill (1990), and Rivkin (2000) are additional references. An analysis of Asian Americans can dramatically change this traditional Black/White paradigm. The very limited literature on Asian Americans has focused on the Chinese, Japanese and Filipino ethnic groups (see, e.g., Mar,

\footnotetext{
${ }^{1}$ Note that "Hispanic origin" is defined as an ethnicity in the U.S. Census, and not a racial category.
}

\footnotetext{
(c)

SOMERIGHISRESERVED Readers are free to copy, display, and distribute this article, as long as the work is attributed to the author(s) and the Journal of Southeast Asian American Education \& Advancement, it is distributed for noncommercial purposes only, and no alteration or transformation is made in the work. More details of this Creative Commons license are available at http://creativecommons.org/licenses/by-nc-nd/3.0/. All other uses must be approved by the author(s) or JSAAEA.
} 
1999, 2000; Yamane, 2002). Furthermore, almost all of the literature on racial discrimination in the labor market has focused on the native-born (see Xie \& Goyette, 2004, for some results on U.S.-born Vietnamese). Since most Asian Americans are foreign-born, it is important to examine the experiences of the immigrant population.

The U.S. Commission on Civil Rights (1988) study of The Economic Status of Americans of Asian Decent: An Exploratory Investigation found that the discrimination faced by foreignborn Vietnamese Americans was comparable to that of the foreign-born Chinese, Filipino, Indian, and Korean Americans using 1980 Census data. Using 1990 Census data, Yamane (2001) found that Vietnamese immigrants experienced labor market discrimination. But all the limited previous work compared Vietnamese immigrants to non-Hispanic White immigrants, many of whom were from advanced industrial countries. Using 2000 Census data, this paper will explore the issue of racial discrimination more carefully by comparing Vietnamese immigrants to nonHispanic White immigrants from Eastern Europe.

When one tests for labor market discrimination, it is important to compare "apples" with "apples." The two comparison groups should be as similar as possible with controls for the ways in which they are different. Previous studies have tested for racial discrimination by comparing Asian immigrant groups to all non-Hispanic White immigrants. But many non-Hispanic White immigrants are from Canada, Britain, and Australia, and may not face serious language and cultural barriers coming to the U.S. Approximately $40 \%$ of immigrants from Europe are from Northern/Western Europe. The non-Hispanic White immigrants from these advanced, industrialized economies are likely to bring skills which are more transferable to the U.S. labor market (see Borjas, 1994). Thus this study compares foreign-born Vietnamese with foreign-born East Europeans because they both face similar language and cultural barriers entering the mainstream U.S. economy.

Using 2000 Census data, one can control for other factors which affect earnings like education, experience, occupation, industry, language ability, etc. One can see if Vietnamese immigrants have earnings comparable to East European immigrants with similar productivity characteristics. One can also see if Vietnamese immigrants have the same access to managerial positions, or whether there is a glass ceiling climbing the corporate ladder. And one can test to see if there are differences in the degree of discrimination at different levels of education, or in different parts of the country.

When Vietnamese immigrants are compared to East European immigrants, Vietnamese men earn $7-9 \%$ less than comparable East European men, with more discrimination among the less educated, and in the larger Vietnamese population centers like California. Vietnamese women earn as much as comparable East European women. Vietnamese immigrants, male and female, are much less likely to hold managerial and supervisory positions than comparable East European immigrants.

\section{Brief Background}

\section{Vietnamese Americans}

Fifty years ago there were only several hundred people of Vietnamese descent living in the United States $^{2}$. With the end of the Vietnam War in 1975, 130,000 Vietnamese refugees made their way to the United States as part of the largest refugee resettlement program in United States

\footnotetext{
${ }^{2}$ Takaki (1989) states that there were 603 Vietnamese Americans in 1964.
} 
history. Since then, the number of Vietnamese coming to the U.S. has increased from 20,000 a year to 29,000 a year. Vietnam generated approximately 350,000 refugees every year in the 1980 s, approximately 500,000 refugees every year in the $1990 \mathrm{~s}$, and about 350,000 refugees every year in the past decade ${ }^{3}$ (See Haines, 2010) for a history of refugees in America.

Today Vietnamese Americans are the fourth largest Asian American ethnic group behind the Chinese, Asian Indians, and Filipinos. From the 2007-09 American Community Survey, 3 Year estimates, Vietnamese Americans represented 10.9\% of all Asian Americans with a population of 1.5 million. Approximately $36.9 \%$ of Vietnamese Americans live in California, 13.3\% live in Texas, 3.9\% live in Washington, and 3.4\% live in Virginia (see Table 1).

Table 1

Population Sizes

\begin{tabular}{lrrr}
\hline $2007-09$ & Total Population & Vietnamese Alone & East European Ancestry \\
\hline Total Population & $304,320,465$ & $1,471,509$ & $21,296,262$ \\
Native-born & $266,230,299$ & 473,810 & $19,102,648$ \\
& $(87.5 \%)$ & $(32.2 \%)$ & $(89.7 \%)$ \\
Foreign-Born & $38,090,166$ & 997,699 & $2,193,614$ \\
& $\left(12.5 \%{ }^{4}\right)$ & $(67.8 \%)$ & $(10.3 \%)$ \\
\hline
\end{tabular}

Notes: American Community Survey 3-Year Estimates, 2007-09

Two-thirds of Asian Americans are foreign-born. The majority of all Asian American ethnic groups are foreign-born except for the Japanese and the Hmong. Most Vietnamese Americans were born abroad as well. In 2007-09, 67.8\% were foreign-born, with 56.4\% having immigrated since 1990. In 2000, 76.1\% were foreign-born, with $48.3 \%$ of the foreign-born having immigrated since 1990. There are approximately one million foreign-born Vietnamese Americans today. They mostly live in California (40.1\%), Texas (12.0\%), Washington (4.0\%), and Florida (3.9\%).

Americans born in Vietnam ${ }^{5}$ were older and less educated than the average American in 2007-09. They had a median age of 42.8, older than the national median of 36.7 years. These Vietnamese Americans were also less likely to have graduated from high school, and slightly less likely to have a bachelor's degree than the average American. The figures are $68.5 \%$ versus $84.9 \%$ for high school, and $23.6 \%$ versus $27.8 \%$ for college for persons 25 years of age and older (see Table 2).

Foreign-born Vietnamese Americans had below average family incomes in 2007-09. The median family income of $\$ 59,296$ was lower than $\$ 62,367$ for all Americans, but their per capita income of $\$ 29,130$ was higher than the $\$ 27,100$ for all Americans. The poverty rate for Vietnamese has been much higher than for all Americans. They had a family poverty rate of $12.2 \%$, much higher than the $9.9 \%$ national average. Labor force participation rates for Vietnamese men and women are a bit higher than the national average.

The seminal studies on the socioeconomic status of Vietnamese Americans include Gold (1992), Gold \& Kibria (1993) and Kibria (1993). Over the past decade the socioeconomic status

\footnotetext{
${ }^{3}$ See the UNHCR Statistical Online Population Database, Total Refugee Population by Origin 1960-2010, at http://www.unhcr.org/pages/4a0174156.html.

${ }^{4}$ The foreign-born population has grown from $7.9 \%$ in 1990 to $11.5 \%$ in 2002 to $12.5 \%$ in 2007-09.

5 Among “Americans born in Vietnam," over $99 \%$ are of Vietnamese ancestry.
} 
of the Vietnamese American community has improved (see more recent work by Le, 2004, 2007; Yang, 2011). Furthermore, the second generation Vietnamese Americans are seeing advances in their socioeconomic status (see Goodwin-White, 2009; Portes, Fernandez-Kelly \& Haller, 2009; Sakamoto \& Woo, 2007).

Table 2

U.S. Population Characteristics

\begin{tabular}{lrrr}
\hline & U.S. Total & Born in & \multicolumn{1}{c}{ Born in } \\
Popu-09 & $304,320,456$ & $1,128,775$ & $2,156,110$ \\
Total Population & 36.7 & 42.8 & 44.1 \\
Median Age & $49.7 \%$ & $64.1 \%$ & $61.4 \%$ \\
Married & 3.21 & 3.93 & 3.17 \\
Average Family Size & $84.9 \%$ & $68.5 \%$ & $87.5 \%$ \\
HS+ & $27.8 \%$ & $23.6 \%$ & $40.7 \%$ \\
BA+ & $64.8 \%$ & $69.2 \%$ & $63.0 \%$ \\
Labor Force Participation Rate & $\$ 62,367$ & $\$ 59,296$ & $\$ 63,962$ \\
Median Family income & $\$ 27,100$ & $\$ 29,130$ & $\$ 32,417$ \\
Per capita income & $9.9 \%$ & $12.2 \%$ & $8.3 \%$ \\
Poverty Rate & $35.1 \%$ & $28.7 \%$ & $37.5 \%$ \\
Management, Professional Occupation & $19.8 \%$ & $93.8 \%$ & $85.9 \%$ \\
Language other than English & & &
\end{tabular}

Notes:

1. American Community Survey 3-Year Estimates, 2007-09.

2. "Born in Vietnam" means Americans-born in Vietnam. They may or may not claim Vietnamese ancestry. The same is true for those "Born in Eastern Europe."

3. HS+: individuals with a high school diploma or an associate's degree

4. BA+: individuals with a bachelor's degree or graduate degree

5. Poverty rate is for families.

\section{East European Americans}

East European immigration has a longer history in North America. The first Polish immigrants were skilled artisans who arrived in Jamestown in 1608. Russian fur traders arrived in Alaska in the mid 1700s, and established posts as far south as Fort Ross (just north of San Francisco) by 1812. The first major wave of immigration from Eastern Europe occurred between the 1880s and the 1920s. With the turmoil of World War I and the Russian Revolution, more than 5.6 million East Europeans arrived in the US for economic, political, and religious reasons. There was little immigration during the Great Depression and World War II with some recovery in the post war period. The second major wave of immigration occurred after the collapse of the Soviet Union in 1990. With the relaxation of emigration restrictions, more than three quarters of a million East Europeans arrived in the U.S. in the decade which followed. Eastern Europe generated over a million refugees every year from 1992 to 2004, peaking with over 2 million refugees in 1996 due to the Balkan conflict ${ }^{6}$.

\footnotetext{
${ }^{6}$ See the UNHCR Statistical Online Population Database, Total Refugee Population by Origin 1960-2010, at http://www.unhcr.org/pages/4a0174156.html.
} 
Today there are about 21.3 million Americans of East European ancestry. East European Americans identify themselves as Polish, Russian, Czech, Hungarian, Ukrainian, Slovak, Lithuanian, Romanian, Croatian, Yugoslavian, Czechoslovakian, Slovenian, Serbian, Albanian, Slavic, Latvian, and Bulgarian. The largest groups are the Polish (10 million), Russian (3.1 million), Czech (1.6 million) and Hungarians (1.5 million). The Polish live predominantly in New York (10.4\%), Illinois (10.1\%), and Michigan (9.1\%). Chicago is the second largest "Polish" city in the world behind Warsaw (See Erdmans, 1998). The Russians live in New York $(15.8 \%)$, California (14.5\%), and Florida (7.6\%). The Czech live in Texas (13.6\%), Illinois (7.9\%), and Minnesota (6.3\%). The Hungarians live in Ohio (14.0\%), New York (10.3\%), and California (8.6\%).

There are 2.2 million foreign-born East European Americans. While 12.5\% of all Americans are foreign-born, only $10.3 \%$ of East European Americans are foreign-born. The vast majority of all East European ethnic groups are native-born except for the Bulgarians and Albanians. Among the foreign-born, the largest groups are the Russians $(533,000)$, Polish $(519,000)$, Ukrainians $(284,000)$, Romanians $(171,000)$, and Yugoslavians $(141,000)$.

The foreign-born East Europeans live in New York (19.5\%), Illinois (13.1\%), California (11.5\%), New Jersey (6.4\%), and Florida (5.7\%). The Russians live in New York (23.9\%), California (15.3\%) and New Jersey (5.5\%). The Polish live in Illinois $(31.6 \%)$, New York $18.7 \%)$, and New Jersey (10.7\%). The Ukrainians live in New York (23.8\%), California (16.6\%), and Washington (8.4\%). The Romanians live in California (15.6\%) and New York (12.9\%). The Yugoslavians live in New York (18.8\%).

Americans born in Eastern Europe were older and more educated than the average American in 2007-09. They had a median age of 44.1, older than the national median of 36.7 years. These East European Americans were also more likely to have graduated from high school, and more likely to have a bachelor's degree than the average American. The figures were $87.5 \%$ versus $84.9 \%$ for high school, and $40.7 \%$ versus $27.8 \%$ for college for persons 25 years of age and older.

East European Americans had above average family incomes in 2007-09. The median family income of $\$ 63,962$ was higher than $\$ 62,367$ for all Americans, and their per capita income of $\$ 32,417$ was higher than the $\$ 27,100$ for all Americans. The poverty rate for East Europeans has been lower than for all Americans. They had a family poverty rate of $8.3 \%$, a bit lower than the $9.9 \%$ national average. Labor force participation rates for East Europeans are lower than the national average.

\section{Similarities and Differences}

Vietnamese and East European immigrants face similar obstacles as they adjust to life in the United States. They come to the U.S. for economic, political, and religious reasons. The East Europeans and Vietnamese have generally come from planned economies, and have to adjust to the market economy of the United States. They are fleeing the disruptions of the Vietnam War and the Yugoslav wars. They are also seeking religious freedom in the U.S.

Most Vietnamese draw their religious beliefs from Mahayana Buddhism, Confucianism, and Taoism. But Vietnamese Americans are much more likely to be Christians than Vietnamese that are residing in Vietnam. While Christians (88\% Roman Catholics) make up about $8 \%$ of Vietnam's total population, they compose as much as $23 \%$ of the total Vietnamese American population. The dominant religion in Poland is Roman Catholicism, and the dominant religion in 
Russia is Russian Orthodox. But immigrants from Eastern Europe have been disproportionately Ashkenazi Jews. All these immigrants confront a U.S. society which is predominantly Protestant Christian.

All immigrants bring with them values and attitudes from their countries of origin which may differ significantly from mainstream U.S. culture. Hofstede (2001) measures national cultures along five dimensions. These are individualism, masculinity, power difference, uncertainty avoidance, and long-term orientation. In individualistic societies, the ties between individuals are loose. Everyone is expected to look after themselves and their immediate families. But in collectivist societies, individuals from birth onward are part of strong in-groups that last a lifetime. In masculine societies, the emotional gender roles are distinct. Men are supposed to be assertive, tough and focused on material success, while women are focused on the quality of life. In feminine societies, the emotional gender roles overlap. Both men and women are supposed to be modest, tender, and focused on the quality of life. Cultures can also be more or less accepting of power differences, uncertainty, and have more or less of a long-term orientation. American culture is extremely high on individualism, above average on masculinity, and below average on acceptance of power differences. On the other hand, both Vietnamese and Russian cultures are the opposite on these three scales. They are low on individualism, below average on masculinity, and above average on acceptance of power differences. In terms of uncertainty avoidance, the Vietnamese are more like Americans. In terms of long-term orientation, the Russians are more like Americans. Overall, Russians and Vietnamese seem more culturally similar to each other than to Americans. And Americans seem most culturally similar to Australians, British, and Canadians.

Recent work on Vietnamese and Eastern European families indicates that they have values which differ from the mainstream American values. Dsilva \& Wyte (1998) find that Vietnamese refugees have a collectivistic, high-context culture which tends to avoid conflict. Robila (2007) finds that East Europeans are less likely to express their impulses, are taught in their culture to be more restrained, less socially assertive, and more humble and reserved. These differences might create challenges for these immigrants in U.S. society and U.S. labor markets.

Both Vietnamese and East European immigrants face language barriers in the U.S. The Polish use the Polish alphabet which corresponds to the Latin alphabet with some additions using diacritics. The Vietnamese use Chữ Quốc Ngữ, based on the Portuguese version of the Latin alphabet with some digraphs and the addition of nine accent marks or diacritics, and the Russians use the Cyrillic (кириллица) alphabet. While Slavic (Russian, Polish, and Czech) and Germanic (English and German) languages fall in the Indio European language family, Vietnamese is in the Austro-Asiatic language family.

There are several significant differences between the Vietnamese immigrants and the East European immigrants. First, their ethnic communities here in the United States are different. While the majority of Vietnamese Americans are foreign-born, the majority of East European Americans are native-born. Consequently, there is a large native-born East European community which may help the recent East European immigrants adjust to life in the United States. Second, the Vietnamese come from a poorer country than the East Europeans. Per capita GDP is \$3,134 in Vietnam, approximately $\$ 14,414^{7}$ in Eastern Europe, and $\$ 47,284$ in the United States in $2010^{8}$. And third, the Vietnamese are Asian and the East Europeans are White.

\footnotetext{
${ }^{7}$ This is weighted by the population shares of the East European immigrants in the United States.

${ }^{8}$ International Monetary Fund, World Economic Outlook Database, April 2011.
} 


\section{Census Data}

This study examines the 2000 Census $^{9}$ of Population and Housing Public Use Microdata Samples (PUMS) prepared by the Bureau of the Census. The PUMS contain records representing $5 \%$ samples and $1 \%$ samples. These samples were combined for this study. The PUMS cover all persons and housing units in the United States. Selected group quarters persons are also included.

In 2000 there were 988,174 foreign-born Vietnamese Americans ${ }^{10}$. There were 1,906,056 foreign-born Americans from Eastern Europe. The East European sample is primarily Polish, Russian, Ukrainian, Romanian, and Hungarian (see Table 3). East European immigrants are more likely to be female than Vietnamese immigrants, $54.2 \%$ vs $51.4 \%$. In fact, over $60 \%$ of immigrants from Lithuania today are female.

Table 3

East European Sample Sizes

\begin{tabular}{lrrr}
\hline 2000 Census PUMS & \multicolumn{1}{c}{ Total } & \multicolumn{1}{c}{ Male } & Female \\
\hline Polish & 16,615 & 7,843 & 8,772 \\
Russian & 11,904 & 5,330 & 6,574 \\
Ukrainian & 6,734 & 3,169 & 3,565 \\
Romanian & 3,717 & 1,851 & 1,866 \\
Hungarian & 3,403 & 1,736 & 1,667 \\
Herzegovinian & 2,075 & 1,063 & 1,012 \\
Albanian & 1,813 & 1,005 & 808 \\
Others & 10,456 & 5,246 & 5,210 \\
Total & 56,717 & 27,243 & 29,474 \\
\hline
\end{tabular}

The focus of this study is on Vietnamese immigrants and East European immigrants between the ages of 25 and 64 who worked more than 26 weeks during the year, worked more than 35 hours per week, were not self-employed, and earned more than $\$ 4,600$ in wage and salary income in $1999^{11}$. With these restrictions, the PUMS give us a sample of 11,168 Vietnamese men, 8,078 Vietnamese women, 17,672 East European men, and 13,334 East European women. The East Europeans are not disaggregated any further because the sample sizes would become much too small to say anything meaningful.

\section{General Characteristics of Foreign-Born Vietnamese}

This study begins by comparing the labor market experience of foreign-born Vietnamese men who worked full-time to the labor market experience of foreign-born East European men who worked full-time. The foreign-born Vietnamese American men are much more likely to live in California and Texas. They are less likely to have a high school degree, a bachelor's degree or a graduate degree. They are younger, less likely to be married, have more kids at home, are less

\footnotetext{
${ }^{9}$ The 2010 Census PUMS are not yet available.

${ }^{10}$ The top five foreign-born populations among US immigrants come from Mexico, China, Philippines, India, and Vietnam.

${ }^{11}$ The minimum wage in 1999 was $\$ 5.15$ an hour.
} 
likely to live in a rural area, immigrated at a slightly younger age, are less likely to speak English well, and earn less than East European men (see Tables 4 and 5).

Table 4

Summary Statistics by Foreign-Born Group

\begin{tabular}{lrrrr}
\hline & $\begin{array}{r}\text { Vietnamese } \\
\text { Men }\end{array}$ & $\begin{array}{r}\text { East European } \\
\text { Men }\end{array}$ & $\begin{array}{r}\text { Vietnamese } \\
\text { Women }\end{array}$ & $\begin{array}{r}\text { East European } \\
\text { Women }\end{array}$ \\
\hline Income & $\$ 37,437$ & $\$ 50,913$ & $\$ 28,649$ & $\$ 35,331$ \\
& $(31,465)$ & $(48,358)$ & $(23,111)$ & $(32,522)$ \\
Education & 12.6 & 14.4 & 12.1 & 14.4 \\
High School \% & 73.8 & 89.2 & 68.2 & 91.0 \\
Bachelor's Degree \% & 26.5 & 43.8 & 23.7 & 45.2 \\
Graduate Degree \% & 6.7 & 23.7 & 5.2 & 21.4 \\
Age & 39.7 & 43.1 & 39.3 & 43.2 \\
& $(10.12)$ & $(10.31)$ & $(9.98)$ & $(10.12)$ \\
Experience & 21.06 & 22.75 & 21.25 & 22.85 \\
& $(11.04)$ & $(10.77)$ & $(11.6)$ & $(10.90)$ \\
Married \% & 68.0 & 78.8 & 66.3 & 70.1 \\
Manager \% & 5.95 & 12.38 & 9.79 & 12.85 \\
Professional \% & 25.28 & 26.77 & 18.32 & 29.04 \\
Hours & 43.4 & 45.48 & 42.1 & 42.5 \\
& $(7.85)$ & $(8.83)$ & $(6.54)$ & $(7.36)$ \\
Weeks & 49.9 & 49.9 & 49.4 & 49.5 \\
Rural \% & $(4.97)$ & $(5.12)$ & $(5.57)$ & $(5.60)$ \\
Immigration Age & 11.3 & 14.3 & 11.4 & 12.9 \\
Language & 24.4 & 25.7 & 24.6 & 25.4 \\
Kids & 1.93 & 1.45 & 1.99 & 1.42 \\
OBS & 0.95 & 0.81 & 0.87 & 0.61 \\
Not & $(1.15)$ & $(1.11)$ & $(1.09)$ & $(0.89)$ \\
& 11,168 & 17,672 & 8,078 & 13,334 \\
\hline
\end{tabular}

Notes:

1. Standard deviation is in parentheses.

2. Income refers to wage and salary income. Education is the number of years of education. Experience is age minus years of education minus 6 . Immigration age is the age at immigration. Language ( 0 means only speaks English, 5 means does not speak English at all). Kids is the number of children at home. OBS is the number of observations.

Foreign-born Vietnamese men are disproportionately in production occupations like assemblers, fabricators, metal workers, plastic workers, inspectors, testers, sorters, and weighers relative to foreign-born East European men. They are under-represented in management, construction, and transportation occupations (see Table 6).

Looking across industries, foreign-born Vietnamese men are disproportionately in durables manufacturing (computers and related equipment; electrical machinery, equipment and supplies; radio, television and communication equipment; aircraft and parts), and non-durables manufacturing. Vietnamese men are under-represented in construction, professional services, education services, and transportation (see Table 7). 
Table 5

Regional Distribution: Percent of Foreign-Born Population

\begin{tabular}{lrrrr}
\hline 1999 & $\begin{array}{c}\text { Vietnamese } \\
\text { Men }\end{array}$ & $\begin{array}{c}\text { East European } \\
\text { Men }\end{array}$ & $\begin{array}{c}\text { Vietnamese } \\
\text { Women }\end{array}$ & $\begin{array}{c}\text { East European } \\
\text { Women }\end{array}$ \\
\hline Northeast & 9.72 & 40.37 & 9.47 & 41.64 \\
Midwest & 8.69 & 25.40 & 8.78 & 24.37 \\
South (except TX) & 18.85 & 12.57 & 19.00 & 12.53 \\
West (except CA) & 10.00 & 8.11 & 11.25 & 7.36 \\
Texas & 11.83 & 2.05 & 11.46 & 2.04 \\
California & 40.91 & 11.50 & 40.03 & 12.05 \\
\hline
\end{tabular}

Table 6

Occupational Distribution: Percent of Foreign-Born Population

\begin{tabular}{lrrrr}
\hline 1999 & $\begin{array}{r}\text { Vietnamese } \\
\text { Men }\end{array}$ & $\begin{array}{r}\text { East European } \\
\text { Men }\end{array}$ & $\begin{array}{c}\text { Vietnamese } \\
\text { Women }\end{array}$ & $\begin{array}{c}\text { East European } \\
\text { Women }\end{array}$ \\
\hline Management & 5.95 & 12.38 & 9.79 & 12.85 \\
Professional & 25.28 & 26.77 & 18.32 & 29.04 \\
Health Service & 0.34 & 0.51 & 1.49 & 5.22 \\
Protective Service & 0.84 & 1.18 & 0.17 & 0.38 \\
Food Service & 4.07 & 2.39 & 3.75 & 3.13 \\
Building Service & 2.53 & 3.60 & 1.82 & 6.55 \\
Personal Service & 3.17 & 0.89 & 8.76 & 3.04 \\
Sales & 4.62 & 5.57 & 5.06 & 7.90 \\
Office & 6.15 & 4.27 & 13.60 & 17.64 \\
Farm & 0.52 & 0.16 & 0.26 & 0.11 \\
Construction & 2.91 & 10.19 & 0.28 & 0.28 \\
Maintenance & 8.26 & 7.74 & 0.83 & 0.43 \\
Production & 30.63 & 16.83 & 33.65 & 11.88 \\
Transport & 4.59 & 7.40 & 2.19 & 1.53 \\
Military & 0.13 & 0.11 & 0.01 & 0.02 \\
\hline
\end{tabular}

The labor market experience of foreign-born Vietnamese women who work full-time is then compared with the labor market experience of foreign-born East European women and men who work full-time. Compared to East European women, Vietnamese women are more likely to live in California and Texas. They are less educated on average than East European women, and earn less. They are younger, more likely to be married, have had more children, are less likely to live in a rural area, immigrated at a slightly younger age, and are less likely to speak English well (see Tables 4 and 5).

Foreign-born Vietnamese women are disproportionately in production occupations (assemblers, fabricators, metal workers, plastic workers, inspectors, testers, sorters, and weighers) and personal services relative to foreign-born East European women. They are underrepresented in management, professional, health service, and building service occupations (see Table 6). 
Table 7

Industry Distribution: Percent of Foreign-Born Population

\begin{tabular}{lrrrr}
\hline 1999 & $\begin{array}{c}\text { Vietnamese } \\
\text { Men }\end{array}$ & $\begin{array}{r}\text { East European } \\
\text { Men }\end{array}$ & $\begin{array}{r}\text { Vietnamese } \\
\text { Women }\end{array}$ & $\begin{array}{c}\text { East European } \\
\text { Women }\end{array}$ \\
\hline Agriculture & 0.60 & 0.26 & 0.15 & 0.12 \\
Mining & 0.21 & 0.16 & 0.07 & 0.04 \\
Utilities & 0.63 & 0.71 & 0.43 & 0.35 \\
Construction & 3.19 & 11.08 & 0.76 & 1.12 \\
Non-Durables Man & 8.19 & 5.93 & 11.24 & 7.21 \\
Durables Man & 37.32 & 22.13 & 29.24 & 10.36 \\
Wholesale Trade & 3.74 & 3.60 & 2.76 & 2.62 \\
Retail & 7.09 & 6.48 & 6.99 & 8.65 \\
Transport & 3.23 & 6.05 & 1.91 & 1.87 \\
Information & 2.86 & 3.38 & 2.28 & 3.18 \\
Finance, Insurance, & 2.90 & 6.35 & 5.87 & 9.58 \\
Real Estate & & & & \\
Professional & 7.47 & 11.30 & 6.41 & 12.64 \\
$\quad$ Services & & & & \\
Education Services & 6.11 & 10.29 & 12.78 & 28.29 \\
Art Service & 6.39 & 4.89 & 6.40 & 5.86 \\
Other Services & 6.98 & 4.18 & 9.90 & 5.22 \\
Public & 2.71 & 2.77 & 2.77 & 2.82 \\
Administration & & & & \\
Military & 0.37 & 0.42 & 0.04 & 0.05 \\
\hline
\end{tabular}

Vietnamese women are disproportionately in industries like durables manufacturing (electrical machinery, equipment and supplies; computer and related equipment; medical, dental and optical instruments and supplies), non-durables manufacturing (apparel and accessories), and other services (nail salons, beauty salons). They are under-represented in education services, professional services, and finance, insurance and real estate (banking; insurance; real estate) (see Table 7).

When foreign-born Vietnamese women are compared to foreign-born East European men, Vietnamese women are found to be much more likely to live in California and Hawaii. They are younger, less educated, more urban, and have been in the country for a shorter period of time (see Tables 4 and 5).

Foreign-born Vietnamese women are disproportionately in occupations like machine operator, assembler and inspectors (assemblers; production inspectors, checkers and examiners), administrative support (bookkeepers, accounting and auditing clerks; data entry keyers), and services (hairdressers and cosmetologists). They are under-represented in management (managers and administrators), professional occupations (post-secondary teachers) and precision production, craft and repair occupations (automobile mechanics; carpenters; machinists) (see Table 6).

Vietnamese women are disproportionately in industries like durables manufacturing (electrical machinery, equipment and supplies; computers and related equipment), and nondurables manufacturing (apparel and accessories, except knit). They are under-represented in construction and transportation (trucking services; air transportation) (see Table 7). 


\section{Current Labor Market Discrimination}

Vietnamese American men earn less, on average, than East European men. They earn about 22\% less both annually and by the hour (see Table 8). Vietnamese American men may have lower average earnings than East European men because of discrimination and/or because of differences in average levels of productive characteristics. Vietnamese women earn less, on average, than East European women, approximately 19\% less. Is this because of discrimination or less education or both? Furthermore, Vietnamese women earn $40 \%$ less than East European men. To what extent is this earnings gap due to gender and racial discrimination?

Table 8

Annual and Hourly Wage and Salary of Foreign-Born

\begin{tabular}{lrrrr}
\hline & $\begin{array}{c}\text { Vietnamese } \\
\text { Men }\end{array}$ & $\begin{array}{c}\text { East European } \\
\text { Men }\end{array}$ & $\begin{array}{c}\text { Vietnamese } \\
\text { Women }\end{array}$ & $\begin{array}{c}\text { East European } \\
\text { Women }\end{array}$ \\
\hline $\begin{array}{c}\text { Annual Wage \& } \\
\text { Salary }\end{array}$ & $\$ 37,436$ & $\$ 50,913$ & $\$ 28,648$ & $\$ 35,331$ \\
$\begin{array}{l}\text { Relative to East } \\
\text { European Men }\end{array}$ & 0.77 & 1.00 & 0.59 & 0.73 \\
$\begin{array}{l}\text { Relative to East } \\
\text { European Women }\end{array}$ & 1.06 & 1.36 & 0.81 & 1.00 \\
& & & & $\$ 16.82$ \\
$\begin{array}{l}\text { Hourly Wage } \\
\text { Relative to East } \\
\text { European Men }\end{array}$ & $\$ 17.41$ & $\$ 22.34$ & $\$ 13.87$ & 0.75 \\
Relative to East & 0.78 & 1.00 & 0.62 & 1.00 \\
$\quad$ European Women & 1.04 & 1.33 & 0.82 & \\
\hline
\end{tabular}

This study proceeds to explore the issue of current labor market discrimination. Current labor market discrimination exists when workers who have identical productive characteristics are treated differently because of their race or gender. The two prominent forms of current labor market discrimination are wage discrimination and occupational discrimination. Wage discrimination occurs when two equally skilled groups of workers doing exactly the same job under the same working conditions are paid different wages. Occupational discrimination occurs when two equally skilled groups of workers are given different access to certain higher-paying occupations.

Using census data, one can estimate the degree to which Vietnamese Americans suffer from current labor market discrimination as narrowly defined above. This study is not attempting to estimate the effect of all the labor market discrimination faced by Vietnamese Americans. More specifically, by taking their productive characteristics as given, this study ignores the effect of pre-market discrimination and past labor market discrimination. Pre-market discrimination refers to different treatment of young Vietnamese Americans before they enter the labor force such as unequal access to quality education. Past labor market discrimination might refer to earlier wage discrimination faced by the parents of these Vietnamese Americans currently in the labor force. Both pre-market discrimination and past labor market discrimination are likely to have affected the nature, quality and amount of education obtained by Vietnamese Americans currently in the labor force and consequently affect their current earnings. But the PUMS dataset 
does not provide enough information to measure the differences in earnings due to discrimination from these and other sources.

\section{Methodology}

The methodology being used, the Oaxaca decomposition, is the standard tool of economists investigating racial and gender discrimination. The data on human capital and other characteristics that are theoretically relevant to the determination of wages is examined first. These include age, education, experience, hours of work, region of residence, industry, occupation, years since immigration, language ability, number of children, and marital status for both Vietnamese American immigrants and East European American immigrants. The study then empirically estimates how each of these characteristics contribute to the earnings of East European Americans. Having measured the levels of the productive characteristics typically possessed by Vietnamese Americans, and having estimated how these characteristics contribute to the earnings of East European Americans, it is possible to estimate how much Vietnamese Americans would be earning if they were treated in the labor market like East European Americans. The difference between their predicted earnings if treated like East Europeans and their actual earnings as Vietnamese is a measure of current labor market discrimination due to race. $^{12}$

More specifically, regressions that relate the earnings of Vietnamese Americans and East European Americans to a wide array of socioeconomic and skill characteristics are estimated. In its simplest form, the earnings functions for each of the two groups could be written as a function of a variable $X$ which might represent the years of education (see Jacob Mincer, 1974). Consider a Vietnamese earnings equation,

$$
w_{V}=\alpha_{V}+\beta_{V} X_{V}
$$

and an East European earnings equation,

$$
w_{E}=\alpha_{E}+\beta_{E} X_{E}
$$

One of the properties of least squares regression is that the regression line goes through the mean of all the variables so that

$$
\bar{w}_{V}=\alpha_{V}+\beta_{V} \bar{X}_{V}
$$

and

$$
\bar{w}_{E}=\alpha_{E}+\beta_{E} \bar{X}_{E}
$$

where the bar above the variable indicates the average value of the variable.

\footnotetext{
${ }^{12}$ The wage offer function for immigrants in a world without racial discrimination is assumed to be the same as the East European wage offer function. This seems reasonable because the number of East European immigrants outnumbers the Vietnamese immigrants by 2 to 1 .
} 
The difference between the average wage of East European Americans and the average wage of Vietnamese Americans can be written as:

$$
\begin{aligned}
\Delta \bar{w}=\bar{w}_{E}-\bar{w}_{V} & =\left(\alpha_{E}+\beta_{E} \bar{X}_{E}\right)-\left(\alpha_{V}+\beta_{V} \bar{X}_{V}\right) \\
& =\alpha_{E}-\alpha_{V}+\beta_{E} \bar{X}_{E}-\beta_{V} \bar{X}_{V} \\
& =\alpha_{E}-\alpha_{V}+\beta_{E} \bar{X}_{E}-\beta_{V} \bar{X}_{V}+\beta_{E} \bar{X}_{V}-\beta_{E} \bar{X}_{V} \\
& =\left(\alpha_{E}-\alpha_{V}\right)-\beta_{V} \bar{X}_{V}+\beta_{E} \bar{X}_{V}+\beta_{E} \bar{X}_{E}-\beta_{E} \bar{X}_{V} \\
& =\left(\alpha_{E}-\alpha_{V}\right)+\left(\beta_{E}-\beta_{V}\right) \bar{X}_{V}+\beta_{E}\left(\bar{X}_{E}-\bar{X}_{V}\right)
\end{aligned}
$$

The last term, $\beta_{E}\left(\bar{X}_{E}-\bar{X}_{V}\right)$, represents the portion of the wage differential which is due to differences in skills. The first two terms represent the portion of the wage differential due to discrimination. Let us call this $d$ :

$$
d=\left(\alpha_{E}-\alpha_{V}\right)+\left(\beta_{E}-\beta_{V}\right) \bar{X}_{V}
$$

This measure tells us the difference between how much Vietnamese Americans are actually paid and how much Vietnamese Americans would be paid if they were treated like East European Americans. Both of these terms can be positive or negative (see Oaxaca, 1973 for details). The actual wage regressions include multiple variables to capture the effect of all the factors which might affect productivity. These variables include education, experience, hours worked, weeks worked, occupation, industry, region, language ability, marital status, disability, and number of children.

For estimating the wage functions, the sample was restricted to people working full-time (35 hours or more per week) for more than half of 1989. These samples contain about $65 \%$ of the men, but only $45 \%$ of the women in the PUMS dataset. If the decision to work full-time is not random with respect to the stochastic error in the wage equation, ordinary least squares regression will give us biased estimates of the wage function coefficients. Since this is likely to be a problem with the female wage equations, the Heckman (1979) selectivity bias correction is used on the female wage equations. A probit equation is estimated to model whether or not an individual is in the sample, and the inverse Mills ratio is included in the wage equation. When controls for selectivity bias are included, the average wage differential can be decomposed into a portion due to differences in average selectivity bias, a portion due to differences in average skills, and a portion due to discrimination. The differences in average selectivity bias may also be decomposed further, a part of which may be interpreted as due to discrimination (see Neuman \& Oaxaca, 1998 for a discussion of various interpretations of the differences in average selectivity bias). Since the appropriate interpretation is unclear, this study will not try to interpret the selectivity bias differences.

\section{Wage Discrimination}

One set of estimated earnings regressions appears on Table 9. The dependent variable in these regressions was the log of annual wages and salaries. All the coefficient estimates are of the expected sign, and most are statistically significant at the 5\% level. People who work more weeks and longer hours earn more. There are positive returns to education and experience. There 
is a penalty for being disabled, having language difficulty, and living in a rural/suburban area. The younger the immigrants are when they arrive, the better off they are.

Table 9

Determinants of Annual Earnings

\begin{tabular}{|c|c|c|c|c|}
\hline 1999 & $\begin{array}{c}\text { Vietnamese } \\
\text { Men }\end{array}$ & $\begin{array}{c}\text { East European } \\
\text { Men }\end{array}$ & $\begin{array}{c}\text { Vietnamese } \\
\text { Women }\end{array}$ & $\begin{array}{c}\text { East European } \\
\text { Women }\end{array}$ \\
\hline \multirow[t]{2}{*}{ Constant } & $8.420^{*}$ & $8.420 *$ & $8.825^{*}$ & $8.122 *$ \\
\hline & $(0.141)$ & $(0.123)$ & $(0.209)$ & $(0.186)$ \\
\hline \multirow[t]{2}{*}{ Weeks } & $0.025^{*}$ & $0.025^{*}$ & $0.020 *$ & $0.029 *$ \\
\hline & $(0.001)$ & $(0.0008)$ & $(0.001)$ & $(0.001)$ \\
\hline \multirow[t]{2}{*}{ Hours } & $0.008 *$ & $0.011^{*}$ & $0.005^{*}$ & $0.012 *$ \\
\hline & $(0.001)$ & $(0.0005)$ & $(0.0008)$ & $(0.0007)$ \\
\hline \multirow[t]{2}{*}{ Education } & $-0.022 *$ & $-0.030 *$ & $-0.032 *$ & $-0.034^{*}$ \\
\hline & $(0.002)$ & $(0.007)$ & $(0.004)$ & $(0.008)$ \\
\hline \multirow[t]{2}{*}{ Education2 } & $0.003 *$ & $0.003 *$ & $0.004^{*}$ & $0.003 *$ \\
\hline & $(0.0002)$ & $(0.0002)$ & $(0.0002)$ & $(0.0003)$ \\
\hline \multirow[t]{2}{*}{ Experience } & $0.020^{*}$ & $0.027^{*}$ & $0.021^{*}$ & $0.020 *$ \\
\hline & $(0.0004)$ & $(0.0016)$ & $(0.002)$ & $(0.0017)$ \\
\hline \multirow{2}{*}{ Experience2 } & $-0.0001 *$ & $-0.0003 *$ & $-0.0002 *$ & $-0.0002 *$ \\
\hline & $(0.00004)$ & $(0.00003)$ & $(0.00004)$ & $(0.00004)$ \\
\hline \multirow[t]{2}{*}{ ImmAge } & -0.001 & $0.005 *$ & $-0.005 *$ & 0.001 \\
\hline & $(0.002)$ & $(0.0011)$ & $(0.002)$ & $(0.0012)$ \\
\hline \multirow[t]{2}{*}{ ImmAge 2} & $-0.0003 *$ & $-0.0003 *$ & $-0.0001 *$ & $-0.0002 *$ \\
\hline & $(0.00003)$ & $(0.00002)$ & $(0.00003)$ & $(0.00004)$ \\
\hline \multirow[t]{2}{*}{ Disability } & 0.008 & $-0.034 *$ & -0.002 & -0.018 \\
\hline & $(0.011)$ & $(0.012)$ & $(0.013)$ & $(0.013)$ \\
\hline \multirow[t]{2}{*}{ Marital } & $0.0889 *$ & $0.127 *$ & 0.011 & 0.009 \\
\hline & $(0.011)$ & $(0.011)$ & $(0.019)$ & $(0.010)$ \\
\hline \multirow[t]{2}{*}{ Suburban } & $-0.031 *$ & $-0.095^{*}$ & $-0.047^{*}$ & $-0.142 *$ \\
\hline & $(0.016)$ & $(0.013)$ & $(0.017)$ & $(0.014)$ \\
\hline \multirow[t]{2}{*}{ Rural } & -0.031 & $-0.171 *$ & -0.101 & -0.080 \\
\hline & $(0.059)$ & $(0.052)$ & $(0.067)$ & $(0.068)$ \\
\hline \multirow[t]{2}{*}{ Kids } & $0.011 *$ & $0.016^{*}$ & -0.001 & -0.002 \\
\hline & $(0.004)$ & $(0.004)$ & $(0.005)$ & $(0.006)$ \\
\hline $\bar{R}^{2}$ & 0.46 & 0.38 & & \\
\hline \multirow[t]{2}{*}{ NOB } & 11,168 & 17,672 & $\begin{array}{r}8,078 \\
\end{array}$ & 13,334 \\
\hline & & & {$[17,364]$} & {$[29,474]$} \\
\hline
\end{tabular}

Notes:

1. Standard errors are in parentheses.

2. * indicates significance at the $5 \%$ level.

3. There were also controls language ability, occupation, industry, class of worker and region of residence.

4. Kids refer to the number of children at home for men, and the total number of births for women.

5. NOB is the number of censored observations. Total observations appear in parentheses. 
Table 10

Expected Earnings of Vietnamese Americans

\begin{tabular}{|c|c|c|c|c|c|c|}
\hline \multirow[t]{2}{*}{1999} & \multicolumn{2}{|c|}{$\begin{array}{l}\text { Vietnamese Men/ } \\
\text { East European Men }\end{array}$} & \multicolumn{2}{|c|}{$\begin{array}{l}\text { East European } \\
\text { Women }\end{array}$} & \multicolumn{2}{|c|}{$\begin{array}{l}\text { Vietnamese Women/ } \\
\text { East European Men }\end{array}$} \\
\hline & A & B & $\mathrm{A}$ & B & $\mathrm{A}$ & $\mathrm{B}$ \\
\hline Actual Annual Earn & $\$ 30,195$ & $\$ 30,195$ & $\$ 23,777$ & $\$ 24,505$ & $\$ 23,777$ & $\$ 24,505$ \\
\hline Predicted Annual Earn & $\$ 33,100$ & $\$ 33,099$ & $\$ 22,309$ & $\$ 24,195$ & $\$ 30,298$ & $\$ 31,113$ \\
\hline Relative Earn & $0.91 *$ & $0.91 *$ & $1.07 *$ & 1.01 & $0.78^{*}$ & $0.79 *$ \\
\hline St Error & $(0.01)$ & $(0.02)$ & $(0.03)$ & $(0.03)$ & $(0.02)$ & $(0.02)$ \\
\hline NOB V & 11,168 & 11,168 & $\begin{array}{r}8,078 \\
{[17364]}\end{array}$ & $\begin{array}{r}8,078 \\
{[17364]}\end{array}$ & $\begin{array}{r}8,078 \\
{[17364]}\end{array}$ & $\begin{array}{r}8,078 \\
{[17364]}\end{array}$ \\
\hline NOB E & 17,672 & 17,672 & $\begin{array}{r}13,334 \\
{[29474]}\end{array}$ & $\begin{array}{r}13,334 \\
{[29474]}\end{array}$ & 17,672 & 17,672 \\
\hline Actual Hourly Wage & $\$ 14.24$ & $\$ 14.24$ & $\$ 11.17$ & $\$ 11.67$ & $\$ 11.17$ & $\$ 11.67$ \\
\hline Predicted Hourly Wage & $\$ 15.35$ & $\$ 15.30$ & $\$ 10.71$ & $\$ 11.14$ & $\$ 14.41$ & $\$ 14.76$ \\
\hline Relative Wage & $0.93 *$ & $0.93 *$ & $1.04 *$ & $1.05 *$ & $0.78 *$ & $0.79 *$ \\
\hline St Error & $(0.02)$ & $(0.02)$ & $(0.02)$ & $(0.03)$ & $(0.02)$ & $(0.02)$ \\
\hline NOB V & 11,168 & 11,168 & $\begin{array}{r}8,078 \\
{[17364]}\end{array}$ & $\begin{array}{r}8,078 \\
{[17364]}\end{array}$ & $\begin{array}{r}8,078 \\
{[17364]}\end{array}$ & $\begin{array}{r}8,078 \\
{[17364]}\end{array}$ \\
\hline NOB E & 17,672 & 17,672 & $\begin{array}{r}13,334 \\
{[29474]}\end{array}$ & $\begin{array}{r}13,334 \\
{[29474]}\end{array}$ & 17,672 & 17,672 \\
\hline
\end{tabular}

Notes:

1. Column A includes industry and occupation controls, column B does not include industry and occupation controls.

2. Region controls were included in all these regressions

3. The dollar figures are the anti-logs of the predicted values. Thus they differ from Table 5 . The average of the logs is not the same as the log of the average.

4. The actual earnings of Vietnamese women differ with and without industry/occupation controls because these are the earnings predicted from wage regressions corrected for sample selection.

5 . * indicates the differences are statistically significant at the 5\% level.

6. Standard errors are in parentheses.

7. Total number of observations (censored and uncensored) appears in brackets.

Being married and having more children is associated with higher earnings for East European and Vietnamese men, but lower earnings for Vietnamese and East European women. These regressions were run with controls for 6 regions of residence, 17 industries and 15 occupations. Similar regressions were run with the log of hourly wages as the dependent variable.

Using these wage regression estimates, the amount of current labor market wage discrimination faced by Vietnamese Americans due to race is estimated. These estimates appear on Table 10. Vietnamese American men are found to earn 7-9\% less than comparable East European men. These differences were significant at the 5\% level. It does not matter whether or 
not you control for industry and occupation. The earnings of Vietnamese women appear to be the same as, or even higher than, the earnings of comparable East European women ${ }^{13}$. But Vietnamese women earn 21-22\% less than comparable East European men.

On average, the Vietnamese and East European immigrants arrived in the United States in their mid 20s. Consequently most of their education was obtained abroad. It might be possible that the quality of education was higher in Eastern Europe than in Vietnam. Before the fall of the Soviet Union, the top students in Vietnam would go to the Soviet Union or Eastern Europe for advanced study. However, the rates of return to education are very similar for Vietnamese Americans and East European Americans. Thus, at least at the margin, the quality of the education seems comparable for both groups.

Another concern is the measure of labor market experience. Experience is defined as age minus years of education minus 6. People in the sample are assumed to enter the labor force when they finish their education and stay there. But only $45 \%$ of the women were selected into the sample, while $65 \%$ of the men were selected into the sample. In terms of hours worked per year, the men report working about 50\% more hours in 1999 than the women. Thus men have a stronger attachment to the labor force than women, and the amount of labor force experience women have relative to men may be overestimated. In order to adjust for this, it may be more reasonable to assume that all men are in the labor force $65 \%$ of the time, and that all women are in the labor force $45 \%$ of the time. Then in a typical year, the average working man would get $44 \%{ }^{14}$ more labor market experience than the average working woman. Thus all the experience measures for the men were increased by $44 \%$, and the wage gaps were re-estimated. Doing so reduced the male/female wage gaps by approximately $7 \%$ points. Rather than earning $21-22 \%$ less than comparable East European men, Vietnamese women earn 14-15\% less than comparable East European men. Thus even after adjusting the experience measure, Vietnamese women are found to experience more wage discrimination than Vietnamese men.

Unfortunately, using this methodology, the amount of racial discrimination and gender discrimination cannot be distinguished. As an illustration, suppose that after controlling for productivity, East European men earn \$100, Vietnamese men earn \$90, East European women earn $\$ 85$, and Vietnamese women earn $\$ 70$. One possibility is that there is uniform racial effect of $\$ 10$, a gender effect for East European women of $\$ 15$, and a gender effect for Vietnamese women of $\$ 20$. Another possibility is that there is a uniform gender effect of $\$ 15$, a racial effect for Vietnamese men of $\$ 10$, and a racial effect for Vietnamese women of $\$ 15$. A third possibility is that there is a uniform racial effect of $\$ 10$, a uniform gender effect of $\$ 15$, and an interaction effect of $\$ 5$ for being a Vietnamese woman. It is impossible to distinguish between these, and an infinite number of other possible scenarios, with this methodology (see Reskin \& Charles, 1999).

Furthermore, the validity of this measure of discrimination depends largely on whether or not controls have been included for all the dimensions in which the skills of the two groups differ. If there are some skill characteristics that affect earnings but were left out of the regression model, these measures of current labor market discrimination would be biased. The actual amount of current labor market discrimination could be higher or lower.

\footnotetext{
${ }^{13}$ The female regression estimates are much less precise than the male regression estimates because of the sample selection issue.

${ }^{14} 44 \%=(65 / 45)-1$
} 


\section{Wage Discrimination by Region}

The relative earnings by region of residence were also examined. Do Vietnamese Americans face more discrimination in certain parts of the country than in others? The relative size of the Vietnamese American population varies significantly as you go east from California to New England. One might expect the amount of wage discrimination to be related to the size of the local population of Vietnamese Americans.

Table 11

Expected Earnings by Region of Residence

\begin{tabular}{|c|c|c|c|c|c|c|c|}
\hline & & Northeast & Midwest & South & West & Texas & California \\
\hline \multirow{6}{*}{$\begin{array}{l}\text { Vietnamese Men / } \\
\text { East European } \\
\text { Men }\end{array}$} & Annual & $0.95 *$ & $0.93 *$ & 1.00 & 0.96 & 0.93 & $0.90 *$ \\
\hline & Earn & $(0.02)$ & $(0.02)$ & $(0.03)$ & $(0.03)$ & $(0.07)$ & $(0.03)$ \\
\hline & Hourly & 0.97 & $0.94^{*}$ & 1.01 & 0.96 & 0.93 & $0.91 *$ \\
\hline & Wage & $(0.02)$ & $(0.02)$ & $(0.03)$ & $(0.03$ & $(0.07)$ & $(0.03)$ \\
\hline & NOB V & 1085 & 971 & 2105 & 1117 & 1321 & 4569 \\
\hline & NOB E & 7135 & 4488 & 2222 & 1433 & 362 & 2032 \\
\hline \multirow{8}{*}{$\begin{array}{l}\text { Vietnamese } \\
\text { Women / East } \\
\text { European Women }\end{array}$} & Annual & $1.06^{*}$ & 0.97 & $1.16^{*}$ & $1.18 *$ & 1.06 & 0.94 \\
\hline & Earn & $(0.03)$ & $(0.03)$ & $(0.04)$ & $(0.04)$ & (0.09) & $(0.05)$ \\
\hline & Hourly & 1.07 & $1.22 *$ & 1.28 & $1.19 *$ & 1.11 & $1.27^{*}$ \\
\hline & Wage & $(0.04)$ & $(0.04)$ & $(0.16)$ & $(0.08)$ & $(0.17)$ & $(0.07)$ \\
\hline & NOB V & 765 & 709 & 1535 & 909 & 926 & 3234 \\
\hline & & [1659] & [1307] & [2950] & [1826] & [1903] & [7719] \\
\hline & NOB E & 5552 & 3250 & 1671 & 982 & 272 & 1607 \\
\hline & & [11992] & [6886] & [3641] & [2476] & [554] & [3925] \\
\hline \multirow{7}{*}{$\begin{array}{l}\text { Vietnamese } \\
\text { Women / East } \\
\text { European Men }\end{array}$} & Annual & $0.84 *$ & $0.73^{*}$ & $0.85^{*}$ & $0.84^{*}$ & $0.72 *$ & $0.83^{*}$ \\
\hline & Earn & $(0.02)$ & $(0.03)$ & $(0.04)$ & $(0.03)$ & $(0.08)$ & $(0.03)$ \\
\hline & Hourly & $0.74 *$ & $0.77 *$ & 0.81 & $0.87^{*}$ & $0.73^{*}$ & $0.82 *$ \\
\hline & Wage & $(0.04)$ & $(0.04)$ & $(0.16)$ & $(0.05)$ & $(0.09)$ & $(0.05)$ \\
\hline & NOB V & 765 & 709 & 1535 & 909 & 926 & 3234 \\
\hline & & [1659] & [1307] & [2950] & [1826] & [1903] & [7719] \\
\hline & NOB E & 7135 & 4488 & 2222 & 1433 & 362 & 2032 \\
\hline
\end{tabular}

Notes:

1. * indicates statistical significance at the $5 \%$ level

2. Industry and occupation controls were included.

3. NOB is the number of censored observations. The total number of observations appears in brackets.

4. West does not include California. South does not include Texas.

5. Standard errors are in parentheses. 
Thus separate wage regressions for East European Americans in each of six different regions were estimated. The study then estimated how much the average Vietnamese in each region should be expected to earn if they were treated like East European Americans. The difference between these predicted earnings and their actual earnings measures the amount of wage discrimination in the region.

The results of this analysis are presented on Table 11. Vietnamese American men face the most wage discrimination in California, their largest population center. The Vietnamese men earn $7-10 \%$ less than comparable East European men in California. Vietnamese men do relatively well in the South. Vietnamese women face the most wage discrimination in Texas and the Midwest, earning 22-28\% less than comparable East European men. They do better in the South (outside of Texas) and the West (outside of California) earning a premium over East European women. The correlation coefficient between the amount of discrimination faced by Vietnamese American men in a region and the amount of discrimination faced by Vietnamese women is positive. Thus the amount of wage discrimination across regions seems to move together for Vietnamese men and women.

It should be noted that some of the standard errors on these estimates are large. In general, the hourly wage regressions are less precise than the annual earning regressions. In some regions, the sample sizes were rather small. And the female regressions with sample selection corrections are always more difficult to estimate. Furthermore, the findings here run contrary to the ethnic enclave literature which argues that demographic concentration is a resource for selfemployed immigrants (who are excluded from the sample). Regional variation is a neglected topic in race and ethnicity studies in the U.S.

\section{Wage Discrimination by Educational Level}

The effect of labor market discrimination on the earnings of Vietnamese may vary according to the level of education. If Vietnamese are denied advancement into high level positions, educated Vietnamese may suffer more, in terms of earnings not commensurate with their education and experience, than persons with less schooling. On the other hand, if anti-Vietnamese discrimination is present in unions and in blue-collar settings, then the earnings of less educated Vietnamese may be more adversely affected by labor market discrimination than is true for more highly educated Vietnamese. Or Vietnamese Americans might face labor market discrimination across the board.

To explore the possibility of a discrimination effect that varies according to educational level, the earnings of Vietnamese and East European immigrants were evaluated at different levels of education. Wage regressions were run for East European immigrants with less than a high school degree, East European immigrants with a high school degree or an associate's degree, and East European immigrants with a bachelor's degree or more. The study compared what Vietnamese immigrants with different levels of education were actually earnings with what one would expect them to be earning if they were treated like East European immigrants with similar levels of education. The results are presented on Table 12.

Vietnamese men see more wage discrimination with lower levels of education, and see no discrimination with a Bachelor's Degree or more. They earn 14-15\% less than comparable East European men when they do not have a high school diploma. More than 30\% of Vietnamese men fall in this category. Vietnamese women see wage discrimination at all levels of education 
relative to East European men, but also see relatively more discrimination at lower levels of education as well.

Table 12

Expected Earnings by Educational Attainment

\begin{tabular}{llrrr}
\hline & & \multicolumn{1}{c}{ HS } & \multicolumn{1}{c}{ HS +} & \multicolumn{1}{c}{$\mathrm{BA}+$} \\
\hline Vietnamese Men / East & Annual Earn & $0.85^{*}$ & $0.90^{*}$ & 1.00 \\
European Men & & $(0.03)$ & $(0.01)$ & $(0.02)$ \\
& Hourly Wage & $0.86^{*}$ & $0.91^{*}$ & 1.02 \\
& & $(0.03)$ & $(0.01)$ & $(0.02)$ \\
& NOB V & 2929 & 5284 & 2955 \\
& NOB E & 1912 & 8020 & 7740 \\
\cline { 2 - 5 } Vietnamese Women / & Annual Earn & 0.98 & 1.01 & $1.14^{*}$ \\
East European Women & & $(0.04)$ & $(0.02)$ & $(0.03)$ \\
& Hourly Wage & 1.26 & 1.13 & $1.41^{*}$ \\
& & $(0.29)$ & $(0.12)$ & $(0.18)$ \\
& NOB V & 2565 & 3597 & 1916 \\
& & {$[7012]$} & {$[7354]$} & {$[2998]$} \\
& & 1196 & 6106 & 6032 \\
& & {$[3627]$} & {$[14199]$} & {$[11648]$} \\
\cline { 2 - 5 } Vietnamese Women / & Annual Earn & $0.74^{*}$ & $0.77^{*}$ & $0.88^{*}$ \\
East European Men & & $(0.04)$ & $(0.02)$ & $(0.03)$ \\
& Hourly Wage & 0.87 & $0.81^{*}$ & 0.98 \\
& & $(0.11)$ & $(0.09)$ & $(0.16)$ \\
& & & & \\
& NOB V & 2565 & 3597 & 1916 \\
& & {$[7012]$} & {$[7354]$} & {$[2998]$} \\
& NOB E & 1912 & 8020 & 7740 \\
\hline
\end{tabular}

Notes:

1. * indicates statistical significance at the $5 \%$ level.

2. <HS: individuals without a high school diploma

3. HS+: individuals with a high school diploma or an associate's degree

4. BA+: individuals with a bachelor's degree or graduate degree

5. Industry, occupation and region controls were included in the regressions

6. Standard errors are in parentheses.

7. NOB means "number of observations." Number of censored and uncensored observations appears in brackets.

Thus obtaining more education decreases the amount of discrimination faced by Vietnamese men and women. Relative to East European women, Vietnamese women with high levels of education even seem to earn a premium. Thus Vietnamese immigrants with less education seem to suffer the most wage discrimination. 


\section{Occupational Discrimination - Glass Ceiling}

In addition to being paid less for doing the same work, Vietnamese Americans may be less likely to be promoted on the job. Vietnamese Americans may be denied equal access to the higher rungs of the managerial or corporate ladder. To the extent that such discrimination exists, Vietnamese Americans may be excluded from spheres of power and influence along with the associated money earnings.

Probit $^{15}$ models were estimated to explain the factors which affect the probability of someone being a manager. Controls for the level of education, for years of experience, disability status, marital status, rural area, language ability, age at immigration, number of kids, and whether or not the person was Vietnamese were included. For Vietnamese women and East European women, probit models with sample selection ${ }^{16}$ were estimated. The probit results are presented on Table 13. All the coefficients were generally of the expected sign and statistically significant. You are less likely to be a manager if you are less educated, have less experience, are disabled, are not married, or have limited language ability. Having more kids decreases the probability that a woman will be a manager. Being Vietnamese also decreases the probability of being a manager. Being a Vietnamese man decreases the probability of being a manager from $4.96 \%$ to $2.62 \%$, making the average Vietnamese man about half as likely to be a manager. Relative to East European women, being a Vietnamese woman decreases the probability of being a manager from $2.41 \%$ to $1.41 \%$. Relative to East European men, being a Vietnamese woman decreases the probability of being a manager from $4.48 \%$ to $2.04 \%$. Thus, Vietnamese men and women are about half as likely to hold managerial positions as East European immigrants with similar characteristics.

Probit models were also estimated to measure the effect of being Vietnamese on the probability of being a supervisor (see Table 13 for the probit results). You are most likely to be a supervisor if you have a high school degree, and very educated individuals are less likely to be a supervisor. People with less experience, who do not speak English well, and who are not married are less likely to be supervisors. Being a Vietnamese man rather than an East European man with identical characteristics decreases the probability of being a supervisor from $5.06 \%$ to $3.99 \%$. Being a Vietnamese woman rather than an East European woman reduces the probability of being a supervisor from $5.96 \%$ to $3.83 \%$. And being a Vietnamese woman rather than an East European man reduces the probability of being a supervisor from $4.64 \%$ to $2.47 \%$. Thus Vietnamese Americans are estimated to be about a third less likely to hold the position of supervisor than East European immigrants with similar characteristics. This is consistent with previous research such as Woo (2000).

The manager and supervisor probit models were also estimated across the six regions. Being Vietnamese, male or female, always decreases the probability of being a manager or a supervisor. The negative effect is generally statistically significant, though the small sample sizes often result in large standard errors. Thus, the glass ceiling for Vietnamese Americans is not restricted to any part of the country.

\footnotetext{
${ }^{15}$ Logit models were also estimated. The results were almost identical, so only the probit results are presented.

${ }^{16}$ See Van de Ven and Van Pragg (1981).
} 
Yamane: Labor Market Discrimination: Vietnamese Immigrants

Yamane_Labor Market Discrimination: Vietnamese Immigrants

Table 13

Probability of Being a Manager/Supervisor

\begin{tabular}{|c|c|c|c|c|c|c|}
\hline \multirow{2}{*}{$\begin{array}{l}1999 \\
\text { Probit }\end{array}$} & \multicolumn{2}{|c|}{$\begin{array}{c}\text { Vietnamese Men/ } \\
\text { East European Men }\end{array}$} & \multicolumn{2}{|c|}{$\begin{array}{l}\text { Vietnamese Women/ } \\
\text { East European Women }\end{array}$} & \multicolumn{2}{|c|}{$\begin{array}{l}\text { Vietnamese Women/ } \\
\text { East European Men }\end{array}$} \\
\hline & Manager & Super & Manager & Super & Manager & Super \\
\hline \multirow[t]{2}{*}{ Constant } & $-2.387 *$ & $-1.936^{*}$ & $-2.566^{*}$ & -0.480 & $-2.270^{*}$ & $-1.608^{*}$ \\
\hline & $(0.287)$ & $(0.274)$ & $(0.651)$ & $(1.248)$ & $(0.337)$ & $(0.309)$ \\
\hline \multirow[t]{2}{*}{ Vietnamese } & $-0.291 *$ & $-0.113^{*}$ & $-0.220 *$ & $-0.213^{*}$ & $-0.347^{*}$ & $-0.285^{*}$ \\
\hline & $(0.033)$ & $(0.034)$ & $(0.041)$ & $(0.046)$ & $(0.039)$ & $(0.041)$ \\
\hline \multirow[t]{2}{*}{ High School } & 0.224 & 0.216 & 0.373 & -0.006 & 0.176 & 0.096 \\
\hline & $(0.161)$ & $(0.113)$ & $(0.236)$ & $(0.135)$ & $(0.181)$ & $(0.131)$ \\
\hline \multirow[t]{2}{*}{ Associate } & $0.498 *$ & 0.208 & $0.534^{*}$ & -0.148 & $0.443 *$ & 0.067 \\
\hline & $(0.164)$ & $(0.119)$ & $(0.240)$ & $(0.145)$ & $(0.185)$ & $(0.138)$ \\
\hline \multirow[t]{2}{*}{ BA } & $0.793 *$ & 0.113 & $0.836^{*}$ & -0.253 & $0.736^{*}$ & -0.010 \\
\hline & $(0.161)$ & $(0.116)$ & $(0.237)$ & $(0.142)$ & $(0.181)$ & $(0.135)$ \\
\hline \multirow[t]{2}{*}{ MA } & $0.997 *$ & -0.015 & $0.998^{*}$ & $-0.294^{*}$ & $0.949 *$ & -0.143 \\
\hline & $(0.163)$ & $(0.122)$ & $(0.240)$ & $(0.149)$ & $(0.183)$ & $(0.140)$ \\
\hline \multirow[t]{2}{*}{ Professional } & $0.426^{*}$ & -0.184 & $0.587^{*}$ & $-0.343^{*}$ & 0.326 & -0.264 \\
\hline & $(0.177)$ & $(0.156)$ & $(0.251)$ & $(0.175)$ & $(0.197)$ & $(0.168)$ \\
\hline \multirow[t]{2}{*}{$\mathrm{PhD}$} & $0.762 *$ & $-0.563^{*}$ & $0.913 *$ & $-0.632 *$ & $0.730 *$ & $-0.723^{*}$ \\
\hline & $(0.171)$ & $(0.178)$ & $(0.257)$ & $(0.247)$ & $(0.191)$ & $(0.196)$ \\
\hline \multirow[t]{2}{*}{ Exp } & $0.038 *$ & $0.014^{*}$ & $0.025^{*}$ & 0.014 & $0.036 *$ & $0.020^{*}$ \\
\hline & $(0.005)$ & $(0.005)$ & $(0.007)$ & $(0.013)$ & $(0.005)$ & $(0.006)$ \\
\hline \multirow[t]{2}{*}{ Exp2 } & $-0.0005^{*}$ & -0.0002 & $-0.0004^{*}$ & -0.0002 & $-0.0005^{*}$ & $-0.0003^{*}$ \\
\hline & $(0.0001)$ & $(0.0001)$ & $(0.0001)$ & $(0.0003)$ & $(0.0001)$ & $(0.0001)$ \\
\hline \multirow[t]{2}{*}{ Disability } & $-0.110 *$ & -0.041 & -0.053 & -0.055 & $-0.089 *$ & 0.029 \\
\hline & $(0.037)$ & $(0.034)$ & $(0.070)$ & $(0.048)$ & $(0.040)$ & $(0.038)$ \\
\hline \multirow[t]{2}{*}{ Marital } & $0.153 *$ & 0.043 & -0.053 & 0.029 & $0.144^{*}$ & 0.020 \\
\hline & $(0.032)$ & $(0.033)$ & $(0.034)$ & $(0.044)$ & $(0.033)$ & $(0.035)$ \\
\hline \multirow[t]{2}{*}{ Suburb } & -0.010 & -0.042 & 0.034 & $-0.175^{*}$ & $-0.123^{*}$ & -0.081 \\
\hline & $(0.039)$ & $(0.041)$ & $(0.047)$ & $(0.062)$ & $(0.041)$ & $(0.045)$ \\
\hline \multirow[t]{2}{*}{ Rural } & -0.062 & 0.056 & 0.096 & -0.080 & -0.015 & 0.056 \\
\hline & $(0.154)$ & $(0.162)$ & $(0.198)$ & $(0.239)$ & $(0.155)$ & $(0.170)$ \\
\hline \multirow[t]{2}{*}{ Kids } & 0.002 & 0.001 & -0.016 & 0.009 & -0.002 & 0.008 \\
\hline & $(0.012)$ & $(0.012)$ & $(0.021)$ & $(0.034)$ & $(0.013)$ & $(0.014)$ \\
\hline \multirow[t]{2}{*}{ ImmAge } & $-0.007 *$ & 0.003 & $-0.014^{*}$ & -0.003 & $-0.007 *$ & -0.0001 \\
\hline & $(0.003)$ & $(0.004)$ & $(0.004)$ & $(0.005)$ & $(0.003)$ & $(0.004)$ \\
\hline \multirow[t]{2}{*}{ ImmAge2 } & -0.00005 & $-0.0002 *$ & 0.00003 & -0.0001 & -0.00004 & -0.0001 \\
\hline & $(0.00007)$ & $(0.00007)$ & $(0.00009)$ & $(0.0001)$ & $(0.00007)$ & $(0.00008)$ \\
\hline Pseudo $R^{2}$ & 0.129 & 0.077 & & & 0.135 & 0.085 \\
\hline \multirow[t]{2}{*}{ NOB } & 28,724 & 28,724 & 21,402 & 21,402 & 25,672 & 25,672 \\
\hline & & & $(46,559)$ & & & \\
\hline
\end{tabular}

Note:

1. Standard errors are in parentheses

2. * indicates statistical significance at the $5 \%$ level. 
3. Manager: 3-digit occupations codes 003-037

4. Supervisor: 3-digit occupation codes 243, 303-307, 413-415, 433, 448, 456, 475, 476, 477, 485, 494, 497, 503, $553-558,613,628,803$, and 843

5. Language ability, industry, and regional controls were included, but are not reported.

6. Education variables are dummy variables representing the individual's highest educational degree. Only 6 out of 15 education dummy coefficients are reported. Kids refers to the number of children at home in the male regressions and the total number of children born in the female regressions.

Unfortunately the census data are flawed in three respects in dealing with the issue of being a manager. One problem is that the category "manager" includes a diverse range of occupational positions from high corporate positions to managers of small retail stores. The census data do not permit distinguishing high-status management positions from other types of management positions. Second, it is possible that individuals are in non-managerial or nonsupervisory jobs because they prefer non-managerial or non-supervisory jobs. For example, Vietnamese immigrants are more likely to hold professional positions than comparable East European immigrants. It is impossible to tell if this is the result of personal choice or discrimination. And third, the census does not distinguish between a person's job responsibilities and the nature of the work.

\section{Conclusion}

According to Omi and Winant (1986), the content and importance of racial categories is determined by social, economic, and political forces. We grow up in our society learning to ascribe social meanings and qualities to otherwise meaningless biological features. Thus, minority colleagues may be viewed as less qualified persons hired to fulfill affirmative action guidelines, and thus deserving lower wages than comparable non-Hispanic White colleagues (see Do, 1998).

In the previous literature, Asian American immigrants have been compared to all nonHispanic White immigrants. But non-Hispanic White immigrants from Canada, Britain, and Australia do not face similar cultural, social, and language barriers when they enter U.S. labor markets. Non-Hispanic White immigrants from advanced industrial countries of Northern Europe may have skills which are more transferable to the U.S. Thus this paper compares Vietnamese immigrants to non-Hispanic White immigrants from Eastern Europe because they both face similar cultural, social, and language barriers entering the U.S.

Examining 2000 Census data, foreign-born Vietnamese Americans are found to face significant discrimination in the U.S. labor market. This study finds that foreign-born Vietnamese men face wage discrimination on the order of $7-9 \%$, and are significantly less likely to hold managerial and supervisory positions than comparable East European men. Vietnamese men in California, and with lower levels of education, experience the most wage discrimination. Foreign-born Vietnamese women face even more wage discrimination than Vietnamese men, and are also less likely to hold managerial and supervisor positions. Relative to East European men, Vietnamese women experience wage discrimination across the country, particularly in Texas and the Midwest, and particularly with lower levels of education. In general Vietnamese women earn as much as comparable East European women. Thus the amount of labor market discrimination faced by foreign-born Vietnamese Americans depends on their gender, their region of residence, and level of education.

Comparing the labor market discrimination of Vietnamese with the literature on African Americans, the patterns are very similar. Most discrimination is for the minority group members 
with low levels of education, and more for male minorities (compared to non-Hispanic White men) than female minorities (compared to non-Hispanic White women). It is clear that Vietnamese immigrants fit within a much broader pattern of White racism and economic inequality.

\section{Acknowledgements}

I would like to thank Marlene Kim, Linda Vo, Hung Thai, Robert Prasch, and three anonymous referees for helpful comments on an earlier draft.

\section{References}

Altonji, J., \& Blank, R. (1999). Race and gender in the labor market. In O. Ashenfelter \& D. Card (Eds.), Handbook of labor economics (pp. 3143-3259). New York: Elsevier.

Bertrand, M., \& Mullainathan, S. (2004). Are Emily and Greg more employable than Lakisha and Jamal? A field experiment on labor market discrimination. American Economic Review, 94(4), 991-1013.

Borjas, G. (1994). The economics of immigration. Journal of Economic Literature, 32, 16671717.

Card, D., \& Krueger, A. (1992). School quality and Black-White relative earnings: A direct assessment. Quarterly Journal of Economics, 107(1), 151-200.

Do, H. D. (1998). The unwanted: Vietnamese refugees in America. In G. R. Campbell (Ed.), Many Americas: Critical perspectives on racism, ethnicity, and cultural identity (pp. 199216). Dubuque, IA: Kendall/Hunt Publishing Company.

Dsilva, M., \& Whyte, L. (1998). Cultural differences in conflict styles: Vietnamese refugees and established residents. Howard Journal of Communications, 9(1), 57-68.

Erdmans, M. P. (1998). Opposite poles: Immigrants and ethnics in Polish Chicago, 1976-1990. University Park: Pennsylvania State University Press.

Gold, S. (1992). Refugee communities: A comparative field study. Newbury Park, CA: Sage Publications.

Gold, S., \& Kibria, N. (1993). Vietnamese refugees and blocked mobility? Asian and Pacific Migration Review, 2(1), 27-56.

Goodwin-White, J. (2009). Emerging contexts of second-generation labour markets in the United States. Journal of Ethnic and Migration Studies, 35(7), 1105-1128.

Haines, D. W. (2010). Safe haven? A history of refugees in America. Sterling, VA: Kumarian Press.

Heckman, J. J. (1979). Sample selection bias as a specification error. Econometrica, 47(1), 153161.

Hofstede, G. (2001). Culture's consequences ( $2^{\text {nd }}$ ed.). Thousand Oaks, CA: Sage Publications.

Kibria, N. (1993). Family tightrope: The changing lives of Vietnamese Americans. Princeton, NJ: Princeton University Press.

Le, C. N. (2004). Fleeing dragon: The refugee experience from a Vietnamese immigrant family. In J. P. Myers (Ed.), Minority voices: Linking personal ethnic history with the sociological imagination (pp. 340-362). Boston, MA: Allyn \& Bacon.

Le, C. N. (2007). Asian American assimilation: Ethnicity, immigration, and socioeconomic attainment. New York: LFB Scholarly Publishing. 
Mar, D. (1999). Regional differences in Asian American earnings discrimination: Japanese, Chinese, and Filipino American earnings in California and Hawaii. Amerasia Journal, 25(2), 67-93.

Mar, D. (2000). Four decades of Asian American women's earnings: Japanese, Chinese, and Filipino American women's earnings 1960-1990. Contemporary Economic Policy, 18(2), 228-237.

Mincer, J. (1974). Schooling, experience, and earnings. Cambridge, MA: NBER.

Neal, D. A., \& Johnson, W. (1996). The role of premarket factors in Black-White wage differences. Journal of Political Economy, 104(5), 869-895.

Neuman, S., \& Oaxaca, R. (1998). Estimating labour market discrimination with selectivity corrected wage equations: Methodological considerations and an illustration from Israel. (Discussion Paper \#1915). London, UK: Centre for Economic Policy Research.

Oaxaca, R. (1973). Male-female wage differentials in urban labor markets. International Economic Review, 14(3), 693-709.

Omi, M., \& Winant, H. (1986). Racial formation in the United States: From the 1960s to the 1980s. New York: Routledge \& Kegan Paul Inc.

O'Neill, J. (1990). The role of human capital in earnings differences between Black and White men. Journal of Economic Perspectives, 4(4), 25-45.

Portes, A., Fernandez-Kelly, P., \& Haller, W. (2009). The adaptation of the immigrant second generation in America: A theoretical overview and recent evidence. Journal of Ethnic and Migration Studies, 35(7), 1077-1104.

Reskin, B. F., \& Charles, C. Z. (1999). Now you see ‘em, now you don't: Race, ethnicity, and gender in labor market research. In I. Browne (Ed.), Race, gender and economic inequality: African Americans and Latina women in the labor market (pp. 380-407). New York: Russell Sage Foundation.

Rivkin, S. (2000). School desegregation, academic attainment, and earnings. Journal of Human Resources, 35(2), 333-46.

Robila, M. (2007). Eastern European immigrants in the United States: A socio-demographic profile. The Social Science Journal, 44(1), 113-125.

Sakamoto, A., \& Woo, H. (2007). The socioeconomic attainments of second-generation Cambodian, Hmong, Laotian, and Vietnamese Americans. Sociological Inquiry, 77(1), 44-75.

Smith, J., \& Welch, F. (1989). Black economics progress after Myrdal. Journal of Economic Literature, 27(2), 519-64.

Takaki, R. (1989). Strangers from a different shore: A history of Asian American. Boston: Little, Brown and Company.

U.S. Commission on Civil Rights. (1988). The economic status of Americans of Asian decent: An exploratory investigation. Washington, DC: U.S. GPO.

Van de Ven, W., \& Van Pragg, B. (1981). The demand for deductibles in private health insurance: A probit model with sample selection. Journal of Econometrics, 17(2), 229252.

Woo, D. (2000). Glass ceilings and Asian Americans. Walnut Creek, CA: Altamira Press.

Xie, Y., \& Goyette, K. (2004). A demographic portrait of Asian Americans. New York: Russell Sage Foundation and Population Reference Bureau.

Yamane, L. (2001). The labor market status of foreign-born Vietnamese. Unpublished manuscript, Pitzer College, Claremont, CA. 
Yamane, L. (2002). Native-born Filipina/o Americans and labor market discrimination. Feminist Economics, 8(2), 125-144.

Yang, P. Q. (2011). Asian immigration to the United States. Cambridge, UK: Polity Press.

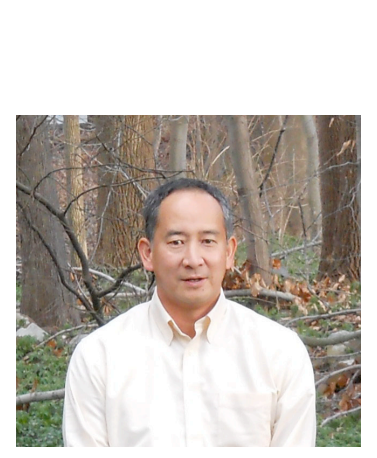

\section{About the Author}

Linus Yamane is a professor of Economics and Asian American Studies at Pitzer College in Claremont, California. He received his doctorate in economics from Yale University. He conducts research on Asian Americans and labor market discrimination, and was the founding chair of the Intercollegiate Department of Asian American Studies at the Claremont Colleges. 


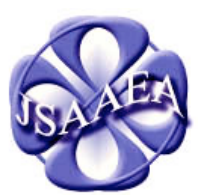

Volume 7 (2012)

\section{Journal of Southeast Asian American Education \& Advancement}

\author{
WwW.JSAAEA.org
}

\section{Editor}

Dr. Wayne E. Wright

University of Texas, San Antonio

\author{
Associate Editors \\ Dr. Chhany Sak-Humphry \\ University of Hawaii at Manoa
}

Dr. Phitsamay Sychitkokhong Uy

University of Massachusetts, Lowell

\section{Book Review Editor}

Dr. Vichet Chhuon

University of Minnesota

\section{Creative Works Editor \\ Bryan Thao Worra \\ Lao Assistance Center}

Special Advisor

Gregory Green

Curator, Echols Collection on Southeast Asia, Cornell University Library

Journal Manager

Sovicheth Boun

University of Texas, San Antonio
A peer-reviewed scholarly journal published by the

National Association

for the Education \&

Advancement of

Cambodian, Laotian,

and Vietnamese

Americans (NAFEA)

Comments and questions for the editorial staff may be directed to jsaaea@1ists.sis.utsa.edu

\section{Editorial Review Board}

\author{
Dr. Steve Arounsack \\ California State University, Stanislaus \\ Dr. Phala Chea \\ Lowell Public Schools \\ Dr. Loan Dao \\ Cancer Prevention Institute of California \\ Dr. Sophal Ear \\ U.S. Naval Postgraduate School \\ Dr. Nancy H. Hornberger \\ University of Pennsylvania \\ Dr. Peter Nien-Chu Kiang \\ University of Massachusetts, Boston
}

Dr. Carl L. Bankston III

Tulane University

Dr. George Chigas

University of Massachusetts, Lowell

Dr. Changming Duan

University of Missouri, Kansas City

Dr. Jeremy Hein

University of Wisconsin - Eau Claire

Dr. Samlong Inthaly

Minneapolis Public Schools

Dr. Kevin K. Kumashiro

University of Illinois, Chicago 


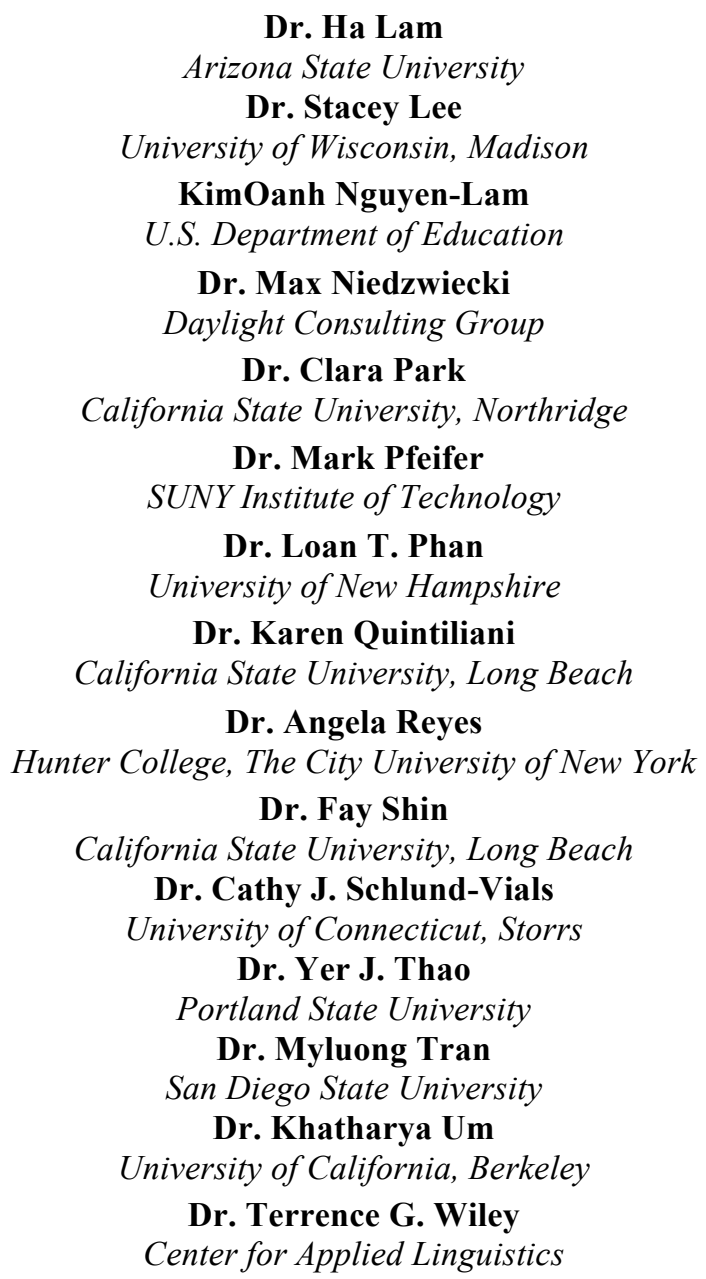

Dr. Ha Lam

Arizona State University

Dr. Stacey Lee

University of Wisconsin, Madison

KimOanh Nguyen-Lam

U.S. Department of Education

Dr. Max Niedzwiecki

Daylight Consulting Group

Dr. Clara Park

California State University, Northridge

Dr. Mark Pfeifer

SUNY Institute of Technology

Dr. Loan T. Phan

University of New Hampshire

Dr. Karen Quintiliani

California State University, Long Beach

Dr. Angela Reyes

Hunter College, The City University of New York

Dr. Fay Shin

California State University, Long Beach

Dr. Cathy J. Schlund-Vials

University of Connecticut, Storrs

Dr. Yer J. Thao

Portland State University

Dr. Myluong Tran

San Diego State University

Dr. Khatharya Um

University of California, Berkeley

Dr. Terrence G. Wiley

Center for Applied Linguistics

Dr. Jonathan H. X. Lee

San Francisco State University

Dr. Sue Needham

California State University, Dominguez Hills

Dr. Bic Ngo

University of Minnesota

Dr. Leakhena Nou

California State University, Long Beach

Dr. Isabelle Thuy Pelaud

San Francisco State University

Dr. Giang Pham

University of Minnesota

Dr. Bounlieng Phommasouvanh

Minnesota Department of Education

Dr. Kalyani Rai

University of Wisconsin, Milwaukee

Dr. Soveacha Ros

Royal University of Phnom Penh

Dr. Nancy J. Smith-Hefner

Boston University

Dr. Christine Su

Ohio University

Dr. Loan Tran

University of California, Riverside

Dr. Tinou Tran

Alief Independent School District

Dr. Linda Trinh Vo

University of California, Irvine

Dr. Zha Blong Xiong

University of Minnesota

Dr. Kou Yang

California State University, Stanislaus

\section{Doctoral Student Editorial Review Board}

\author{
Keo Chea-Young \\ University of Pennsylvania \\ Ketmani Kouanchao \\ California State University, Fullerton \\ Ravy Lao \\ University of California, Santa Barbara \\ Thien-Huong Ninh \\ University of Southern California \\ Vanna Som \\ Harvard University \\ Krissyvan Truong \\ Claremount Graduate University \\ Yang Sao Xiong \\ University of California, Los Angeles
}

\author{
Annie BichLoan Duong \\ San Joaquin County Office of Education \\ Peter Tan Keo \\ Columbia University \\ Monirith Ly \\ Texas State University-San Marcos \\ Malaphone Phommasa \\ University of California, Santa Barbara \\ Alisia Tran \\ University of Minnesota \\ Silvy Un \\ University of Minnesota \\ Yeng Yang \\ University of Texas, San Antonio
}

